\title{
Functionality of the plastron in adults of Neochetina eichhorniae Warner (Coleoptera, Curculionidae): aspects of the integument coating and submersion laboratory experiments
}

\author{
Wesley Oliveira de Sousa ${ }^{1}$, Germano Henrique Rosado-Neto² \& Marinêz Isaac Marques ${ }^{3,4}$
}

\begin{abstract}
${ }^{1}$ Curso de Agronomia, Instituto de Ciências Exatas e da Terra, Universidade Federal de Mato Grosso, Campus Universitário do Araguaia. Avenida Governador Jaime Campos, 6390, Drurys, 78600-000 Barra do Garças-MT, Brasil. entomoi@hotmail.com

${ }^{2}$ Departamento de Zoologia, Universidade Federal do Paraná. Caixa Postal 19020, 81531-980 Curitiba-PR, Brasil. rosadoneto@ufpr.br

${ }^{3}$ Programa de Pós-graduação em Ecologia e Conservação da Biodiversidade, Instituto de Biociências, Universidade Federal de Mato Grosso. Avenida Fernando Correa da Costa, 2367, Boa Esperança, 78060-900 Cuiabá-MT, Brasil.

${ }^{4}$ Bolsista Produtividade do Conselho Nacional de Desenvolvimento Científico e Tecnológico.marinez@ufmt.br
\end{abstract}

\begin{abstract}
Functionality of the plastron in adults of Neochetina eichhorniae Warner (Coleoptera, Curculionidae): aspects of the integument coating and submersion laboratory experiments. The plastron theory was tested in adults of Neochetina eichhorniae Warner, 1970, through the analysis of the structure that coats these insects' integument and also through submersion laboratorial experiments. The tegument processes were recognized in three types: agglutinated scales with large perforations, plumose scales of varied sizes and shapes, and hairs. The experiments were carried out on 264 adult individuals which were kept submerged at different time intervals $(\mathrm{n}=11)$ and in two types of treatment, natural non-aerated water and previously boiled water, with four repetitions for each treatment. The tests showed a maximum mortality after 24 hours of immersion in the previously boiled water treatment. The survival of the adults was negative and significantly correlated with the types of treatment employed and within the different time intervals. The values of oxygen dissolved in water $(\mathrm{mg} / \mathrm{l})$ differed significantly within the types of treatment employed. They were positively correlated with the survival of the adults in the two types of treatment, although more markedly in the treatment with previously boiled water. The mortality of adults after 24 hours of submersion in the treatment with previously boiled water may be associated with the physical-chemical conditions of the non-tested water in this study, such as low surface tension and concentration of solutes. These results suggest plastron functionality in the adults of this species.
\end{abstract}

KEYWORDS. Hypoxia; Pantanal; plastron; Stenopelmini; weevil.

RESUMO. Funcionalidade do plastrão em adultos de Neochetina eichhorniae Warner (Coleoptera, Curculionidae): aspectos do revestimento tegumentar e experimentos laboratoriais de submersão. A teoria plastrão foi testada em adultos de Neochetina eichhorniae Warner, 1970, por meio da análise da estrutura que reveste o tegumento destes insetos e em experimentos laboratoriais de submersão. Os processos tegumentares foram reconhecidos em três tipos: escamas aglutinadas e com perfurações largas; escamas plumosas de tamanhos e formas variadas; e pêlos. Os experimentos realizados com 264 indivíduos adultos os quais permaneciam submersos por diferentes intervalos de tempo $(\mathrm{n}=11)$ e em dois tratamentos, água natural não aerada e água previamente fervida, com quatro repetições para cada tratamento, revelaram uma mortalidade máxima após 24 horas de mergulho no tratamento água previamente fervida. A sobrevivência dos adultos foi negativa e significativamente correlacionada com os tratamentos empregados e entre os diferentes intervalos de tempo. Os valores de oxigênio dissolvido $(\mathrm{mg} / \mathrm{l})$ na água diferiram significativamente entre os tratamentos aplicados, sendo positivamente correlacionado com a sobrevivência dos adultos nos dois tratamentos, embora mais acentuadamente no tratamento com água previamente fervida. A mortalidade dos adultos após 24 horas de mergulho no tratamento com água previamente fervida pode estar associada às condições físico-químicas da água não testadas neste estudo, como, por exemplo, baixa tensão superficial e concentração de solutos. Estes resultados sugerem uma funcionalidade do plastrão nos adultos desta espécie.

PALAVRAS-CHAVE. Hipoxia; Pantanal; plastrão; Curculionidae; Stenopelmini.

The specializations related to the type of aquatic breathing in Coleoptera may be recognized by the accumulation of air, in bubble format, under the elytra and/or through the plastron (Spangler 1981). The theory about the working of the plastron breathing was studied by Thorpe \& Crisp (1947a, b, 1949).

According to Hinton (1966, 1969a, b), the plastron is defined as a layer of gas with constant volume, trapped by hydrofuge hairs or processes which coats the insects' integument, resistant to hydrostatic pressure, and which works as a physical gill, contributing to a normal breathing, allowing a submersion for indefinite periods of time (Krivosheina 2005).
Hinton (1976) adds that the plastron arose independently in three subfamilies within the Curculionoidea, Erirhininae (Stenopelmini), Cylidrhorhininae (Listroderini, currently a tribe of Cyclominae, according Bouchard et al. 2011) and Ceutorhynchinae, with records in at least six genera allocated in Stenopelmini such as Brachybamus Germar, 1835, Cyrtobagous Hustache, 1929, Grypus Germar, 1817, Lissorhoptrus LeConte, 1876, Neochetina Hustache, 1926 and Notiodes Schoenherr, 1838 (=Endalus Laporte, 1840), also suggesting that this kind of adaptation may have evolved more than once inside some of these genera. 
Research on the plastron in different groups of insects in adult, immature and egg stages often address physical aspects (Thorpe \& Crisp 1947a, b, 1949; Hinton 1966, 1969b, 1976) or structural aspects (Hinton 1969a, b, 1976; Murillo \& Jirón 1994; Selivon \& Perondini 1999; Lopez-Ruf et al. 2000; Lópes-Ruf \& Goodwyn 2001; Sukontanson et al. 2004). However, for the weevils they only refer to the structural aspects of the tegument coating that assists in forming the plastron, which are treated briefly in taxonomic descriptions (e.g. Kuschel 1952; O’Brien \& Wibmer 1989; Wibmer \& O’Brien 1989; O’Brien 1996).

The weevils belonging to the genus Neochetina Hustache (1926), can be used as good models in inferential studies on the functionality of the plastron, as they are very similar taxonomically (O'Brien 1976), with behavioral and morphological characteristics to survive in aquatic environments (DeLoach 1975; O'Brien 1976). Neochetina eichhorniae Warner, 1970 was selected for this study because of its wide geographical distribution and abundance in Neotropical ecosystems, its adaptation to water bodies through close relationship with its host plant, Eichhornia crassipes (Mart.) Solms (Pontederiaceae), the presence of a specialized coating with water-repellent hairs and scales, and its behavioral adaptations such as the ability to dive and swim (DeLoach 1975, 1976; DeLoach \& Cordo 1976a,b; O’Brien 1976; Buckingham \& Passoa 1985; Center \& Dray Jr.1992; Heard \& Winterton 2000).

Therefore, it appears that there is a gap in the knowledge about the actual functionality of the plastron in insects, mainly in relation to the maximum and minimum limits for survival of these organisms when submerged. Due to this, a description of the structure coating the tegument of $N$. eichhorniae and submersion tests in laboratorial conditions are presented, with the aim of testing the efficiency of the plastron in the adults of this species, by quantifying the maximum and minimum limits of survival when submerged, and correlating the survival and/or mortality with the values of oxygen dissolved in water and submersion time. This information is necessary and highly relevant for the comprehension of the general patterns of the biodiversity distribution, as they generate information about the biology and history of life, geographical and habitat distribution, as well as the skills and tolerances of each species to survive in aquatic environment in wetlands.

\section{MATERIAL AND METHODS}

The study of the structure that evolves the integument of $N$. eichhorniae as well as the laboratorial experiments were carried out with adult individuals collected from October to November 2007 in 10 oxbow lakes along the course of the Cuiabá River, in the Pantanal of Barão de Melgaço-MT, Brazil, with the aid of a Vieira \& Adis (2002) modified cage model with $0,25 \mathrm{~m}^{2}$ allocated on macrophyte banks compounded, in their majority, by E. crassipes.

The structure of the integument processes with water-repellent characteristics coating the $N$. eichhorniae integument was described according to Hinton (1976) and Hix et al.
(2003), and the images generated in a scanning electron microscope model LEO 435 VP from Instituto Nacional de Pesquisas da Amazônia, Manaus, Brazil.

The submersion experiments were carried out between November and December of 2007, in the Taxonomy and Ecology of Arthropods Laboratory of the Graduation Program in Ecology and Biodiversity Conservation of the Universidade Federal de Mato Grosso, Cuiabá, Brazil, in non-controlled conditions of temperature and luminosity.

The collected adult weevils were mixed in $500 \mathrm{ml}$ plastic pots and then randomly selected for the experiments. This procedure was adopted to reduce possible effects of pseudo phylogenetic repeat that could affect the results and the interpretation of the data.

A total of 11 time intervals of submersion was tested $(n=$ 11) during the period of 24 hours. The water collected from the Cuiabá River used to test each time interval of submersion was treated under two conditions $(n=2)$, natural nonaerated water kept in an open container, and previously boiled for one hour kept in a closed container. For each of these 11 time intervals and treatments four repetitions $(n=4)$ were performed. Each repetition was carried out in a plastic glass with $250 \mathrm{ml}$ of water, where a "voil" bag with three $N$. eichhorniae adults of unknown age and sex $(n=3)$ were submerged, used just once in each time interval, treatment and repetition. A sterilized marble was used to keep the bag submerged. At the end of each submersion interval the bag was withdrawn from the water and the individuals transferred to Petri plates with filter paper for later survival assessment verified through vital responses such as locomotor or appendage movements, after mechanically stimulating the individuals with the help of entomological tweezers.

The values of dissolved oxygen in water $(\mathrm{mg} / \mathrm{l})$ of the two treatments were measured at the beginning and at the end of each time interval of submersion, using a probe model YSI 556 MPS.

The results were analyzed using trend charts and hypothesis tests at a significance level of 5\%. A logistic regression was applied to investigate possible differences in survival among the two treatments, different time intervals, and to test the relationship between the survivals of individuals with the values of oxygen dissolved $(\mathrm{mg} / \mathrm{l})$ in water used in the two treatments. The nonparametric Kruskal-Wallis test was used to assess probable significant differences in the values of oxygen dissolved in water $(\mathrm{mg} / \mathrm{l})$ of the two different treatments and time intervals. All the analyses were performed in the SYSTAT 11 program (Wilkinson 2004).

\section{RESULTS}

Neochetina eichhorniae possess three types of processes with water-repellent characteristics coating the integument, which may contribute to plastron formation. These are: $1-$ agglutinate scales with large perforations (Fig. 1); 2 - plumose scales of varied sizes and shapes (Figs. 2-4), and 3 hairs (Fig. 5). 

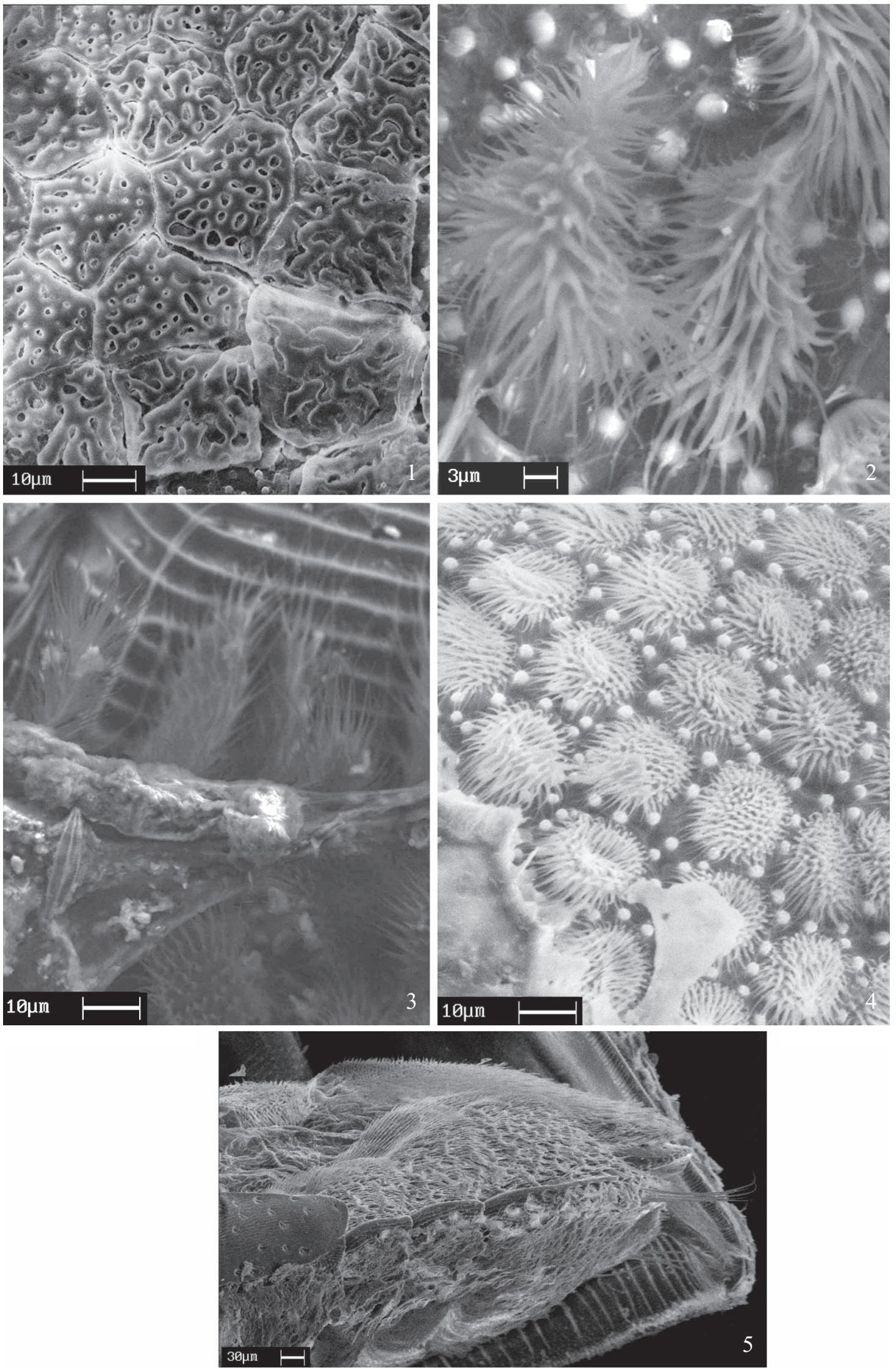

Figs. 1-5 Neochetina eichhorniae: 1, agglutinate scales with large perforations of the pronotum; 2 , prosternal plumose scales; 3 , plumose scales of the scutellar region, between the pronotum and the elytra; 4 , plumose scales of the mesoleg; 5 , tergo abdominal hairiness. 
A total of $264 N$. eichhorniae adults were tested in submersion experiments. The higher survival rate (and consequently the lower mortality) was observed in the treatment with natural non-aerated water, and the lower survival rate/ higher mortality was observed in the treatment with previously boiled water (Fig. 6).

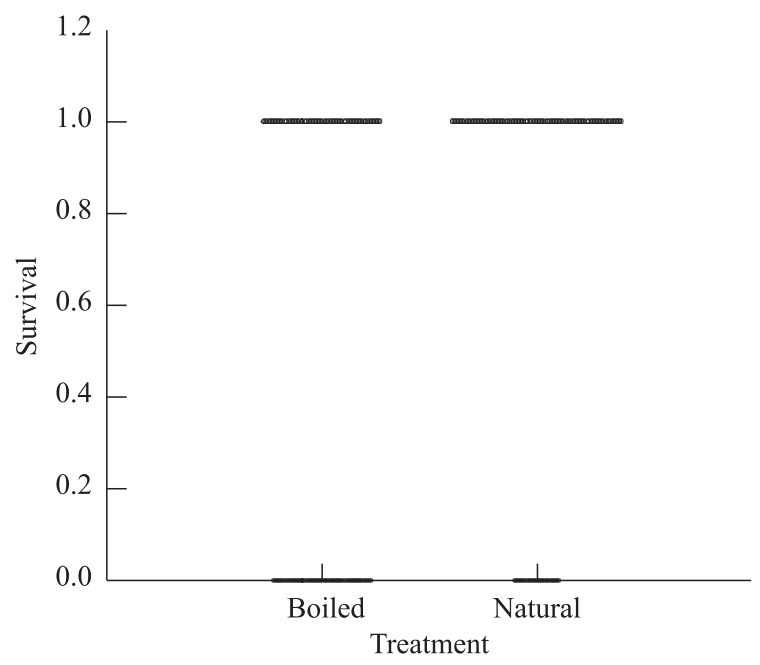

Fig. 6. Survival of adult Neochetina eichhorniae in boiled and in natural non-boiled water, after $24 \mathrm{~h}$ of submersion.

The increase of mortality within the $N$. eichhorniae adults were observed from the submersion time of four hours in the treatment with previously boiled water (Fig. 7). Whereas when the water was untreated (natural non-aerated) the survival rate was higher (Fig. 8).

In the treatment with natural non-aerated water, the individuals survived for a longer submersion time, after $24 \mathrm{~h}$, whereas in the treatment with previously boiled water, they survived after $20 \mathrm{~h}$ of submersion (Figs. 7-8). The survival was negatively correlated with the treatment and time of submersion $\left(\chi^{2}=73,103 ; \mathrm{df}=2 ; \mathrm{p}<0.001\right)$.

The values of oxygen dissolved in water were significantly lower in the treatment with previously boiled water than those in natural non-boiled water $(\mathrm{U}=468,000$; $\mathrm{df}=1$; $\mathrm{p}<0.001$ ) (Fig. 9), and were positively correlated with the $N$. eichhorniae survival. The results were not significant for the treatment with natural non-boiled water $\left(\chi^{2}=2,991 ; \mathrm{df}=1\right.$; $\mathrm{p}>0.05)$ and significant in the treatment with previously boiled water $\left(\chi^{2}=15,322 ; \mathrm{df}=1 ; \mathrm{p}<0.001\right)$ (Figs. 10-11).

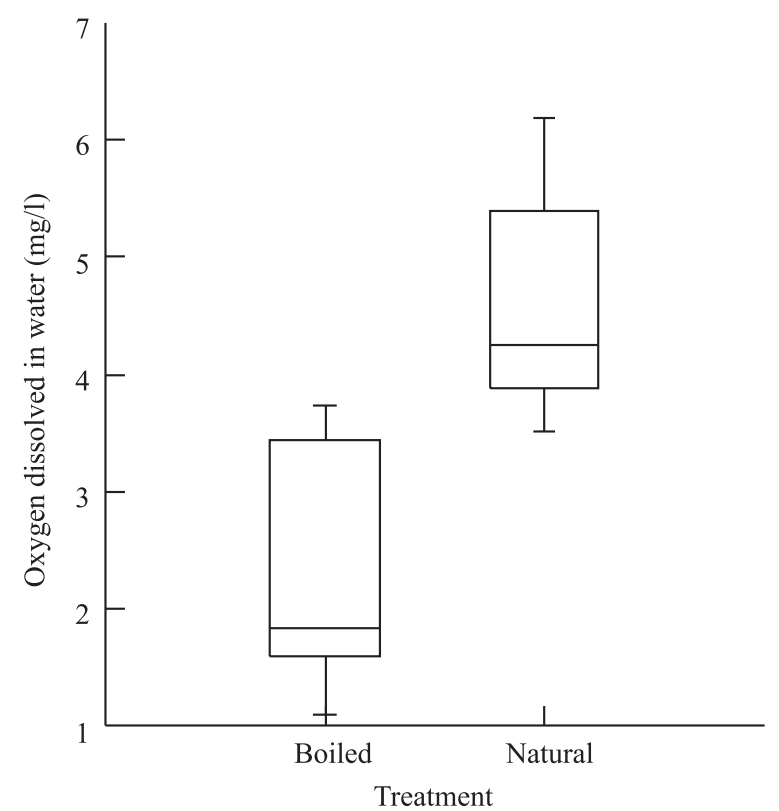

Fig. 9. Values of oxygen dissolved in water $(\mathrm{mg} / \mathrm{l})$ in the treatment with boiled and natural non-boiled water used in different time intervals of submersion with Neochetina eichhorniae adults.
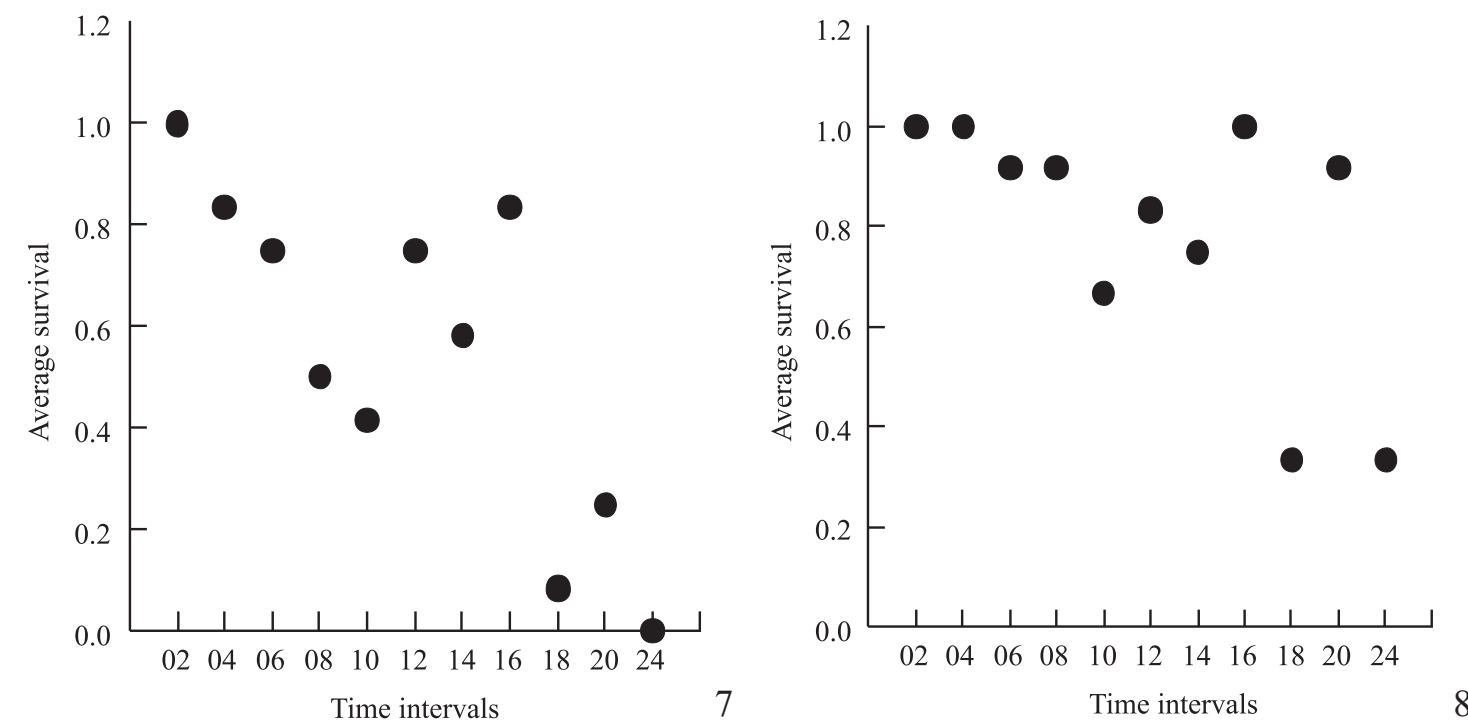

Figs. 7-8. Average survival of Neochetina eichhorniae adults in different time intervals of submersion: 7, previously boiled water; 8, natural non-boiled water. 

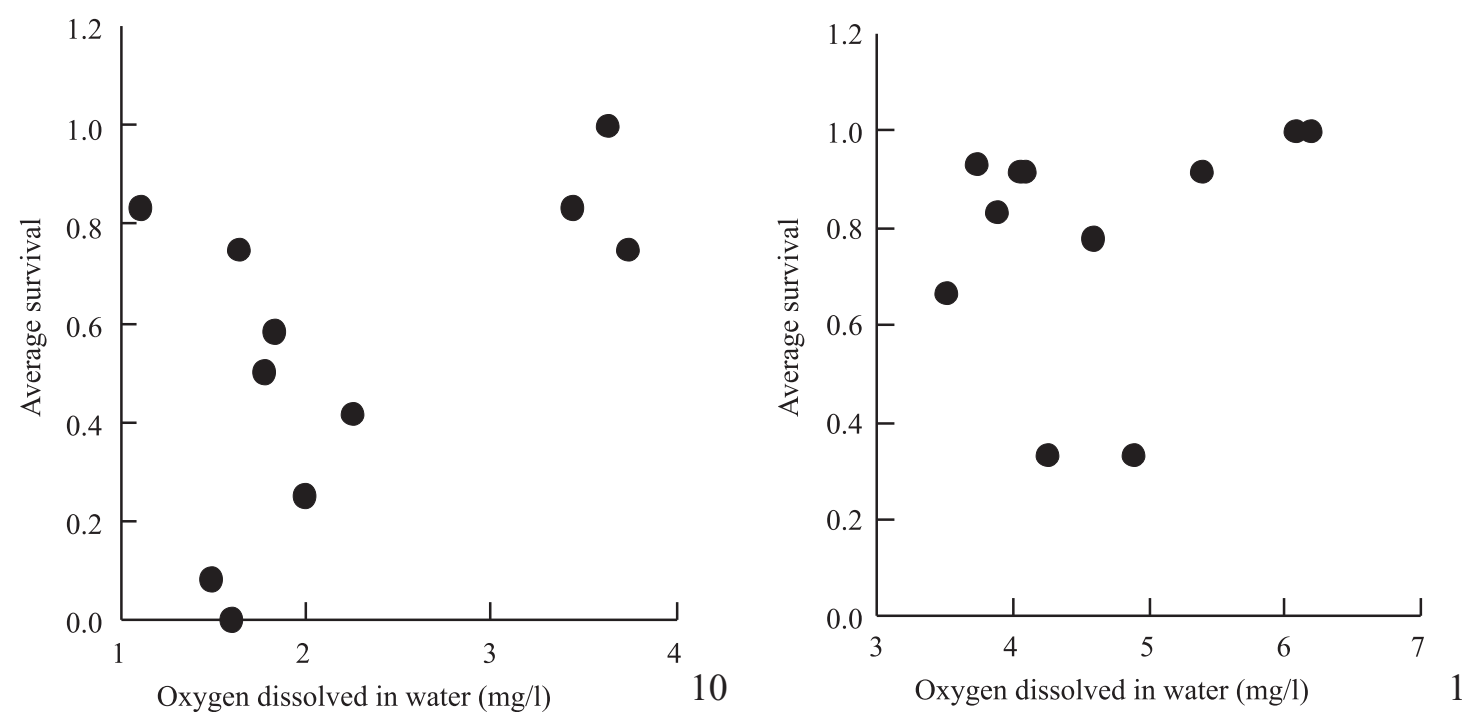

Figs. 10-11. Relationship between the survivals of Neochetina eichhorniae individuals with the dissolved oxygen (mg/l): 10, in treatments with boiled water; 11 , in treatments with non-boiled water.

After the removal of individuals from the water under both conditions, it was observed that individuals submerged for shorter periods of time (two to eight hours), still remained active, i.e. normal locomotor movements, responding to mechanical stimuli when handled with entomological tweezers. The individuals submerged after eight hours, when removed from the water, were found in a latency stage, with no locomotor movements, but returning to their normal activities and responding to mechanical stimuli after some time. Although time intervals were not systematically quantified, they varied from minutes to hours.

\section{DISCUSSION}

Integument structures, such as agglutinate or plumose scales, and hairs, which coat the tegument of the weevils under study, are fundamental components for the functioning of the plastron (Spangler 1981). The agglutinate scales occur over most of the dorsal and ventral surface of both males and females of $N$. eichhorniae, except for points of articulation, coxae, inner surface of tibiae, and parts of abdominal ventrites (O’Brien 1976), which may be lined with plumose scales, or hairs. In these species the agglutinate scales have large perforations that contribute to the increase of water-air interface, and consequently, the efficiency of the plastron. Vertical pillars that in some taxa support the scales and increase the plastron efficiency are, however, absent (Hinton 1976).

Plumose scales coat the rostrum "upper-escrobal" sulcus, the base of the head, the mid-prosternal region, large part of the coxae and the inner edge of the tibia of the $N$. eichhorniae (O'Brien 1976). In other Stenopelmini, these scales may coat the integument completely or incompletely, e.g., Neohydronomus affinis Hustache, 1926 and Argentinorhynchus breyeri Brèthes, 1910, respectively. In spite of being common in the Stenopelmini, illustrations and information about the functionality of their type of scale in the operation of the plastron have been published by Thorpe \& Crisp (1949), based on the study of Eubrychius velutus (Beck, 1817) and Tanysphyrus lemmnae (Fabricius, 1792) and by Hix et al. (2003) for Lissorhoptrus oryzophilus Kuschel, 1952.

The densely distributed hairs on the abdominal tergites of $N$. eichhorniae contribute to the functionality of the plastron and are closely associated with its area, which is determined by the density and structural conformation of the hydrophobic integument processes (Thorpe \& Crisp 1949). According to these authors, beetles that present scales with high hair density (Figs. 2-4) have, consequently, a larger area of plastron. Amongst the weevils this structure is also formed with the aid of scales which can be glabrous or perforated (Fig. 1). In groups in which these scales are not perforated, the water-air interface area is smaller, and the plastron is limited to the spacing between them. Species that have scales with small perforations sustained by vertical pillars, such as L. oryzophilus, may have a plastron of greater efficiency (Hinton 1976), allowing permanent submersion of up to 96 hours in natural conditions (Hix et al. 2000). The scales of the $N$. eichhorniae have large perforations (Fig. 1), which contribute to the water-air interface, and thus, the efficiency of the plastron. However, contrary to what occurs in L. oryzophilus, the vertical pillars that sustain the scales and improve the plastron functionality are absent in the N. eichhorniae (Hinton, 1976).

In the treatment with previously boiled water lower survival, or higher mortality, of the $N$. eichhorniae was obtained in almost all of the time intervals, and total mortality, after 24 $\mathrm{h}$ of submersion, correlated with the lower quantity of dissolved oxygen. However, the boiling process both significantly reduces the quantity of oxygen and the water volume through evaporation; the latter may cause an increase in the concentration of dissolved organic matter and, consequently, a decrease of surface tension of the water used in the experiments (Hoback \& Stanley 2001; Hebets \& Chapman 2000). This in turn may promote a decrease in the functionality of the plastron, which is 
sensitive to changes in the surface tension of water under normal hydrostatic pressure conditions (Thorpe \& Crisp 1947a, b).

Total mortality was registered during the treatment with previously boiled water after $24 \mathrm{~h}$ of submersion, but not in natural non-aerated water (although the trend line indicated that mortality could have been found if the individuals had remained submerged for a period longer than $24 \mathrm{~h}$ ). These results corroborate the plastron functionality in N. eichhorniae.

They also suggest that the physical-chemical characteristics of water in artificial conditions of laboratory experiments were limiting to the ventilation of these insects. In natural environments such characteristics are favorable and different from laboratory conditions, consequently potentially leading to a greater length of time of submersion.

The biology of $N$. eichhorniae requires that adults remain submerged for short periods of time throughout their lives at times of emergency, to escape high temperatures, or from predators (DeLoach 1975, 1976; DeLoach \& Cordo 1976a, b; O'Brien 1977) or for longer period such as at times of flood (that occur rapidly in the environment) (Hinton 1966, 1969a).

The stage of latency observed in N. eichhorniae individuals, with short or long periods of submersion, is attributed in this study to hypoxia. The ventilation performed using the plastron reduced the dissolved oxygen in the water in both treatments, causing a hypoxia condition occurring more rapidly in the treatment with boiled water, and more slowly in natural non-aerated water. Insects respond to the condition of hypoxia through various strategies such as reduction of metabolic and respiratory rates, and the reduction of the production of ATP. This process causes a decrease in locomotor movements of insects (Hoback et al. 2000; Zerm \& Adis 2003), as observed during this experiment. It is likely therefore that the condition of hypoxia influenced the respiratory rate, affecting the production of ATP, decreasing the motor activity of $N$. eichhorniae individuals submerged for short periods in previously boiled water and for periods longer than eight hours in natural non-aerated water.

The integument structures and the survival of the $N$. eichhorniae adults after 24 hours of submersion in the treatment with natural non-aerated water, the negative and significant correlation of the survival with both treatments tested and time intervals, as well as the positive correlation with the dissolved oxygen, demonstrate that the $N$. eichhorniae adults are able to perform an underwater ventilation through the plastron using directly the oxygen dissolved in water. These results corroborate the knowledge of the biology and morphology of the species and theories about the functionality of the plastron in Curculionidae, explaining the prevalence of Stenopelmini species such as $N$. eichhorniae in aquatic environments.

\section{ACKNOWLEDGEMENTS}

To the Conselho Nacional de Desenvolvimento Científico e Tecnológico (CNPq), Fundação de Amparo à Pesquisa do Estado de Mato Grosso, Projeto Ecológico de Longa Duração do Pantanal Norte (PELD-UFMT) and Instituto Nacional de
Pesquisas da Amazônia for financial support. To Professor Joachim Adis in memorian.

\section{REFERENCES}

Bouchard P.; Y. Bousquet; A. E. Davies; M. A. Alonso-Zarazaga; J. F. Lawrence; C. H. C. Lyal; A. F. Newton; C. A. M. Reid; M. Schmitt; S. A. Elipiñski \& A. B. T. Smith. 2011. Family-group names in Coleoptera (Insecta). Zookeys 88:1-972.

Buckingham, G. \& S. Passoa. 1986. Flight muscle and egg development in waterhyacinth weevils, p. 497-510. In: E. S. Delfosse (ed.). Proceeding of VI International Symposium of Biological Control Weeds. Vancouver, Agriculture Canada, 537 p.

Center, T. D. \& F. A. Dray Jr. 1992. Associations between waterhyacinth weevils (Neochetina eichhorniae and N. bruchi) and phenological stages of Eichhornia crassipes in southern Florida. Florida Entomologist 75 : 196-211.

DeLoach, C. J. 1975. Identification and biological notes on the species of Neochetina that attack Pontederiaceae in Argentina (Coleoptera: Curculionidae: Bagoini). Coleopterists Bulletin 29: 257-265.

DeLoach, C. J. 1976. Neochetina bruchi, a biological control agent of waterhyacinth: host specificity in Argentina. Annals of the Entomological Society of America 69: 635-642.

DeLoach, C. J. \& H. A. Cordo. 1976a. Ecological studies of Neochetina bruchi and $N$. eichhorniae on waterhyacinth in Argentina. Journal of Aquatic Plant Management 14: 53-59.

DeLoach, C. J. \& H. A. Cordo. 1976b. Life cycle and biology of Neochetina bruchi, a weevil attacking waterhyacinth in Argentina, with notes on $N$. eichhorniae. Annals of the Entomological Society of America 69: 643652.

Heard, T. A. \& S. L. Winterton. 2000. Interactions between nutrient status and weevil herbivory in the biological control of water hyacinth. Journal of Applied Ecology 37: 117-127.

Hebets, E. A. \& R. F. Chapman. 2000. Surviving the flood: plastron respiration in the non-tracheate arthropod Phrynus marginemaculatus (Amblypygi: Arachnida). Journal of Insect Physiology 46: 13-19.

Hinton, H. E. 1966. Plastron respiration in marine insects. Nature 209: 220-221.

Hinton, H. E. 1969a. Plastron respiration in adult beetles of suborder Myxophaga. Journal of Zoology 159: 131-137.

Hinton, H. E. 1969b. Respiratory systems of insect egg shells. Annual Review of Entomology 14: 343-368.

Hinton, H. E. 1976. Plastron respiration in bugs and beetles. Journal of Insect Physiology 22: 1529-1550.

Hix, R. L.; D. T. Johnson \& J. L. Bernhardt. 2000. An aquatic barrier trap for monitoring adult rice water weevils (Coleoptera: Curculionidae). Florida Entomologist 83: 189-192.

Hix, R. L.; D. T. Johnson \& J. L. Bernhardt. 2003. Antenal sensory structures of Lissorhoptrus oryzophilus (Coleoptera: Curculionidae) with notes on aquatic adaptations. The Coleopterists Bulletin 57: 85-94.

Hoback, W. W. \& D. W. Stanley. 2001. Insects in hypoxia. Journal of Insects Physiology 47: 533-542.

Hoback, W. W.; J. E. Podrabsky; L. G. Higley; D. W. Stanley \& S. C. Hand. 2000. Anoxia tolerance of con-familial tiger beetle larvae is associated with differences in energy flow and anaerobiosis. Journal of Comparative Physiology B: Biochemical, systemic and environmental physiology 170: $307-314$.

Krivosheina, M. G. 2005. The plastron is a universal structure that ensures breathing of dipteran larvae both in the water and in the air. Doklady Biological Science 401: 112-115.

Kuschel. G.1952. Revision de Lissorhoptrus LeConte y gêneros vecinos de América. Revista Chilena de Entomología 1: 23-74.

López-Ruf, M. L. \& P. J. P. Goodwyn. 2001. Description of the eggs of Curicta bonaerensis (Berg) (Heteroptera: Nepidae). Revista de la Sociedad Entomológica Argentina 60: 69-72.

Lopez-Ruf, M. L.; G. N. Pellerango \& A. O. Bachmann. 2000. Ventilatory structures in Cryphocricos barozzii Signoret (Heteroptera, Naucoroidea). 
Revista Brasileira de Biologia 60: 267-273.

Murillo, T. \& L. F. Jirón. 1994. Egg morphology of Anastrepha obliqua and some comparative aspects with eggs of Anastrepha fraterculus (Diptera: Tephritidae). Florida Entomologist 77: 342-348.

O'Brien, C. W. 1976. A taxonomic revision of the new world subaquatic genus Neochetina (Coleoptera: Curculionidae: Bagoini). Annals of the Entomological Society of America 69: 165-174.

O’Brien, C. W. 1977. Curculionidae, p. 245-247. In: S. H. Hurlbert (ed.). Biota acuática de Sudamérica Austral. San Diego, San Diego State University, $342 \mathrm{p}$.

O'Brien, C. W. 1996. Two new Lissorhoptrus rice pests in Northern South America, with a Revision of the Species in Colombia and Venezuela (Coleoptera: Curculionidae). Transactions of the American Entomological Society 122: 115-134.

O’Brien, C. W \& G. J. Wibmer. 1989. Revision of the Neotropical Genus Neohydronomus Hustache (Coleoptera: Curculionidae). The Coleopterists Bulletin 43: 291-304

Selivon, D. \& A. L. P. Perondini. 1999. Description of Anastrepha sororcula and A. serpentina (Diptera: Thephritidae) eggs. Florida Entomologist 82: 347-353.

Spangler, P. J. 1981. Coleoptera, p. 129-220. In: S. H Hurlbert; G. Rodriguez \& N. D. dos Santos (eds.). Aquatic Biota of Tropical South America. Part 1.Arthropoda. California, San Diego State University, xii+323 p.
Sukontason, K.; K. L. Sukontason; N. Boonchu; T. Chaiwong. \& S. Piangjai. 2004. Ultrastructure of eggshell of Chrysomya nigripes Aubertin (Diptera: Calliphoridae). Parasitology Research 93: 151-154.

Thorpe, W. H \& D. J. Crisp. 1947a. Studies on plastron respiration I. The biology of Aphelocheirus [Hemiptera, Aphelocheiridae (Naucoridae)] and the mechanism of plastron retention. Journal of Experimental Biology 24: 227-269.

Thorpe, W. H \& D. J. Crisp. 1947b. Studies on plastron respiration II. The respiratory efficiency of the plastron in Aphelocheirus. Journal of Experimental Biology 24: 270-303.

Thorpe, W. H \& D. J. Crisp. 1949. Studies on plastron respiration IV. Plastron respiration in the Coleoptera. Journal of Experimental Biology 26: 219-260.

Vieira, M. F. \& J. Adis. 1992. Abundância e biomassa de Paulinia acuminata (De Geer, 1773) (Orthoptera: Paulinidae) em um lago de várzea da Amazônia central. Amazoniana 12: 337-352.

Wibmer, G. J \& C. W. O’Brien. 1989. Two new Neotropical Genera in the Weevil Tribe Stenopelmini. Southwestern Entomologists 14: 395-407. Wilkinson L. 2004. Systat, Version 11.0. San José, Software Inc.

Zerm, M. \& J. Adis. 2003. Exceptional anoxia resistance in larval tiger beetle, Phaeoxantha klugii (Coleoptera: Cicindelidae). Physiological Entomology 28: 150-153 